\title{
Combination Therapy of Peginterferon and Ribavirin for Chronic Hepatitis C Patients with Genotype 1b and Low-virus Load
}

\author{
Yasuji Arase ${ }^{1}$, Fumitaka Suzuki ${ }^{1}$, Norio Akuta ${ }^{1}$, Hitomi Sezaki ${ }^{1}$, Yoshiyuki Suzuki ${ }^{1}$, \\ Yusuke Kawamura ${ }^{1}$, Masahiro Kobayashi ${ }^{1}$, Tetsuya Hosaka ${ }^{1}$, Hiromi Yatsuji ${ }^{1}$, \\ Miharu Hirakawa ${ }^{1}$, Satoshi Saito ${ }^{1}$, Kenji Ikeda ${ }^{1}$, Mariko Kobayashi ${ }^{2}$ and Hiromitsu Kumada ${ }^{1}$
}

\begin{abstract}
Objective The aim of this study was to evaluate the efficacy of combination therapy of peginterferon and ribavirin in patients infected with hepatitis $\mathrm{C}$ virus $(\mathrm{HCV})$ genotype $1 \mathrm{~b}$ and low virus load.

Methods Inclusion criteria were HCV-genotype $1 \mathrm{~b}$, serum HCV RNA level of $<100 \mathrm{KIU} / \mathrm{mL}$ at the initiation time of treatment. A total of 60 were enrolled in this retrospective cohort study. The treatment period of combination therapy was $39.8 \pm 16.1$ weeks.

Results Of the 60 study patients, 47 had sustained virological response (SVR) by the intention to treat analysis. SVR occurred when serum HCV RNA was negative 8 weeks after the initiation of the treatment ( $p=0.004)$ and continuance of negative HCV RNA during treatment was $\geq 30$ week ( $p=0.016$ ). In rapid virological response, all of seven patients with continuance of negative HCV RNA 20 to 29 weeks during treatment had SVR. In early virological response nine of 10 patients with continuance of negative HCV RNA of 30 to 39 week during treatment had SVR.

Conclusion The duration of combination therapy for chronic hepatitis $\mathrm{C}$ should be determined based on the time of attainment of negative HCV RNA in patients with genotype $1 \mathrm{~b}$ and low-virus load.
\end{abstract}

Key words: chronic hepatitis C, peginterferon, ribavirin, HCV genotype $1 b$, low virus load, duration of treatment

(Inter Med 48: 253-258, 2009)

(DOI: 10.2169/internalmedicine.48.1629)

\section{Introduction}

Current evidence indicates that combination therapy of peginterferon and ribavirin for hepatitis $\mathrm{C}$ virus $(\mathrm{HCV})$ is associated with a higher rate of sustained virological response (SVR) compared with interferon (IFN) alone (1-7). Hence, combination therapy of peginterferon and ribavirin has been recommended as a first choice for chronic hepatitis $\mathrm{C}$ patients with high virus-load. Now, the selection of duration of treatment and optimum doses of combination therapy is an area of active investigation (8-16).

However, the dropout rates in patients treated with combi- nation therapy was higher than those treated with IFN monotherapy $(17,18)$. On the other hand, some authors have reported that in half of the patients with a low virus load HCV RNA is eradicated by IFN monotherapy. Thus, for patients with a low virus load IFN monotherapy has been recommended as a first choice in Japan. However, there is also controversy over which patients should be treated with what agent and what regimen as a first choice for good prolonged prognosis in chronic hepatitis $\mathrm{C}$ patients with a low virus load. There is an ongoing need to refine treatment strategies in patients with a low virus load.

Thus, in the present study, we performed a retrospective study to examine the efficacy of combination therapy in pa-

${ }^{1}$ Department of Hepatology, Toranomon Hospital, Tokyo and ${ }^{2}$ Hepatic Research Unit, Toranomon Hospital, Tokyo Received for publication August 25, 2008; Accepted for publication October 21, 2008 Correspondence to Dr. Yasuji Arase, es9y-ars@asahi-net.or.jp 
tients with genotype $1 \mathrm{~b}$ and low virus load. Additionally, the relationship between attainment time of negativity of serum HCV RNA after the initiation of combination therapy and the continuance of negative HCV RNA in patients with genotype $1 \mathrm{~b}$ and low HCV-RNA load of $<100 \mathrm{KIU} / \mathrm{mL}$ were also evaluated.

\section{Materials and Methods}

\section{Patients}

Eligibility criteria for entry into the study included the following: 1) HCV genotype $1 \mathrm{~b}$; 2) serum level of HCV RNA of $<100 \mathrm{KIU} / \mathrm{mL}$ before treatment; 3) no corticosteroid, immunosuppressive agents, or antiviral agents used within 6 months; 4) no hepatitis B surface antigens (HBsAg), antinuclear antibodies (ANA), or antimitochondrial antibodies (AMA) detectable in serum, determined by radioimmunoassay; 5) leukocytes $>2,000 / \mathrm{mm}^{3}$, platelet count $>80,000 / \mathrm{mm}^{3}$, and bilirubin $\left.<2.0 \mathrm{mg} / \mathrm{mL} ; 6\right)$ follow up for $>6$ months before treatment. We excluded from the study all of the patients with the following: 1) a history of alcohol abuse; 2) advanced liver cirrhosis of encephalopathy, bleeding esophageal varices, or ascites. The physician in charge explained the purpose and method of the combination therapy as well as the potential adverse reactions to each patient and informed consent was obtained from each patient.

From December 2004 to May 2007, $60 \mathrm{HCV}$ patients were enrolled in this retrospective cohort study at the study hospital.

Patients were classified into three groups according to their response to combination therapy: rapid virological response (RVR), defined as undetectable HCV RNA at week 4 after the initiation of combination therapy; early virological response (EVR), defined as undetectable HCV RNA at week, 5 to 12 of combination therapy; and late virological response (LVR), defined as undetectable HCV RNA at week 13 to 24 of combination therapy. A SVR was defined as clearance of $\mathrm{HCV}$ RNA by commercial amplicor $\mathrm{HCV}$ qualitative assay (Amplicor HCV; Ver.2.0, Roche Diagnostic Systems, Basel, Switzerland) at 6 months after the cessation of combination therapy (19).

Next, predictors of SVR in patients with undetectable HCV RNA in serum during treatment were assessed by the multiple logistic regression analysis. Finally, SVR rate based on the attainment time of negativity of HCV RNA and continuance of negative HCV RNA during combination therapy were examined.

\section{Combination therapy of pegylated-IFN and ribavirin}

For the treatment regimen, the peginterferon (Peg-intron, Schering-Plough Pharmaceutical Co., Osaka, Japan) and ribavirin (Rebetol, Schering-Plough) were given at the dose described based on body weight. At the initiation of combination therapy, patients received peginterferon at a median dose of $1.4 \mu \mathrm{g} / \mathrm{kg}$ (range, 1.3-1.7 $\mu \mathrm{g} / \mathrm{kg}$ ) subcutaneously each week and oral ribavirin at a median dose of $12.0 \mathrm{mg} /$ $\mathrm{kg}$ (range, 9.9-14.9 $\mathrm{mg} / \mathrm{kg}$ ) daily. The peginterferon dose was adjusted according to body weight $(60 \mu \mathrm{g}$ for $\leq 40 \mathrm{~kg}$, $80 \mu \mathrm{g}$ for $>40 \mathrm{~kg}$ and $\leq 60 \mathrm{~kg}, 100 \mu \mathrm{g}$ for $>60 \mathrm{~kg}$ and $\leq 80$ $\mathrm{kg}, 120 \mu \mathrm{g}$ for $>80 \mathrm{~kg}$ and $\leq 100 \mathrm{~kg}$, and $150 \mu \mathrm{g}$ for $>100$ $\mathrm{kg})$. The ribavirin dose was adjusted according to body weight $(600 \mathrm{mg}$ for $\leq 60 \mathrm{~kg}, 800 \mathrm{mg}$ for $>60 \mathrm{~kg}$ and $\leq 80$ $\mathrm{kg}$, and $1,000 \mathrm{mg}$ for $>80 \mathrm{~kg}$ ). The regimen or treatment period was decided by the physician. A total of 39 patients were treated with a 48 -week regimen and 16 patients were given combination therapy for a 24 -week regimen. Treatment for the remaining five patients was discontinued because of treatment-related side effects within 26 weeks after the initiation of combination therapy.

Blood samples were obtained just before and 6 month after combination therapy. The samples were stored at $-80^{\circ} \mathrm{C}$ until analyzed. Using these blood samples, HCV-RNA level before IFN therapy was analyzed by quantitative PCR assay (Amplicor GT-HCV Monitor Version 2.0, Roche Molecular Systems) (20). HCV-genotype was examined by polymerized chain reaction assay, using a mixture of primers for the six subtypes known to exist in Japan, as reported previously (21). Serum alanine aminotransferase (ALT), aspartate aminotransferase (AST) concentrations, and HCV RNA were measured at least once per month during therapy. Negativity of serum HCV RNA was defined as clearance of serum HCV RNA by commercial amplicor HCV qualitative assay (19). Clinical evaluation and biochemical and hematological tests were performed at 4 weekly intervals.

\section{Liver histology before IFN therapy}

Liver biopsy specimens were obtained percutaneously under the observation by laparoscopy using a modified Vim Silverman needle with an internal diameter of $2 \mathrm{~mm}$ (Tohoku University style, Kakinuma Factory, Tokyo), fixed in $10 \%$ formalin, and stained with Hematoxylin and Eosin, Masson's trichrome, silver impregnation, and periodic acidSchiff after diastase digestion. The biopsy specimens were diagnosed according to the system of Desmet et al (22).

\section{Statistical analysis}

Nonparametric procedures were employed for the analysis of background features of the patients with SVR and without SVR, including the Mann-Whitney U test. Independent factors that might have influenced SVR were studied using multiple logistic regression analysis, and the following variables were evaluated as prognostic factors: sex, age, body mass index, liver staging, a history of interferon therapy, a history of HCV load of $\geq 100 \mathrm{KIU} / \mathrm{mL}$, HCV RNA level, biochemical factors (AST, ALT), platelet count, HCV RNA 4, 8, 12 week after the initiation of IFN therapy, continuous negative period of HCV RNA during IFN therapy and period of IFN therapy. The SPSS software package (SPSS Inc., Chicago, IL) was used to perform statistical analysis. A $\mathrm{p}$ value of $<0.05$ was considered to indicate a significant difference. 
Table 1. Clinical Backgrounds before Combination Therapy of Peginterferon and Ribavirin in Chronic Hepatitis C Patients

\begin{tabular}{|c|c|c|c|c|c|}
\hline & Total & Response & & & \\
\hline & & RVR & EVR & LVR & $\mathrm{p}$ \\
\hline Patients, $\mathrm{n}^{\dagger}$ & 60 & 18 & 31 & 6 & \\
\hline Sex, male $(\%)^{\dagger}$ & $42(70 \%)$ & $15(83 \%)$ & $23(74 \%)$ & $2(33 \%)$ & 0.063 \\
\hline Age $(\mathrm{yrs})^{\ddagger}$ & $51.9 \pm 10.1$ & $50.8 \pm 9.3$ & $52.1 \pm 10.8$ & $53.9 \pm 10.9$ & 0.713 \\
\hline $\mathrm{BMI}^{\ddagger}$ & $21.9 \pm 3.1$ & $23.2 \pm 3.6$ & $21.2 \pm 2.9$ & $21.9 \pm 2.3$ & 0.177 \\
\hline A history of $\operatorname{IFN}^{\dagger},(\%)$ & $28(47 \%)$ & $7(39 \%)$ & $13(42 \%)$ & $4(67 \%)$ & 0.085 \\
\hline $\begin{array}{l}\text { History of maximum } \\
\text { HCV RNA level of } \\
>100 \mathrm{KIU} / \mathrm{mL}(+/-)^{\dagger}\end{array}$ & $43 / 17$ & $13 / 5$ & $21 / 10$ & $4 / 2$ & 0.498 \\
\hline HCV RNA(KIU/mL) $)^{\S}$ & $52(<5-99)$ & $43(8-93)$ & $58(<5-99)$ & $72(21-90)$ & 0.498 \\
\hline $\operatorname{AST}(\mathrm{IU} / \mathrm{L})^{\ddagger}$ & $58 \pm 32$ & $61 \pm 47$ & $56 \pm 24$ & $51 \pm 18$ & 0.480 \\
\hline $\operatorname{ALT}(\mathrm{IU} / \mathrm{L})^{\ddagger}$ & $73 \pm 52$ & $80 \pm 62$ & $69 \pm 37$ & $82 \pm 59$ & 0.456 \\
\hline $\mathrm{FPG}(\mathrm{mg} / \mathrm{dL})^{\ddagger}$ & $93.1 \pm 13.6$ & $93.2 \pm 13.0$ & $92.5 \pm 12.2$ & $97.5 \pm 24.6$ & 0.182 \\
\hline Triglyceride $(\mathrm{mg} / \mathrm{dL})^{\ddagger}$ & $92.5 \pm 35.2$ & $94.5 \pm 27.8$ & $90.6 \pm 42.9$ & $93.9 \pm 30.2$ & 0.887 \\
\hline Platelet $\left(10^{4} / \mathrm{mm}^{3}\right)^{*}$ & $18.7 \pm 6.3$ & $20.9 \pm 4.7$ & $19.6 \pm 5.9$ & $13.7 \pm 5.6$ & 0.106 \\
\hline $\begin{array}{l}\text { Fibrosis staging }^{\dagger} \\
\text { (Non-LC/LC) }\end{array}$ & $54 / 6$ & $18 / 0$ & $26 / 5$ & $5 / 1$ & 0.067 \\
\hline
\end{tabular}

\footnotetext{
*ALT, alanine aminotransferase; AST, aspartate aminotransferase; BMI, body mass index; EVR, early virological response; FPG, fasting plasma glucose; HCV, hepatitis $\mathrm{C}$ virus; IFN, interferon; LC, liver cirrhosis; LVR, late virological response; $\quad \mathrm{RVR}$, rapid virological response Normal reference ranges 6-50 IU/L for ALT, 11-38 IU/L for AST,

${ }^{\dagger}$ Data expressed as number of patients (percentage)

${ }^{\ddagger}$ Data expressed as mean \pm standard deviation

${ }^{\S}$ Data expressed as median (range)
}

\section{Result}

\section{Clinical characteristics of the patients}

A total of 60 patients were enrolled on present study. Table 1 shows the characteristics of the patients who received combination therapy. Clinical profiles were as follows: mean age $=52$ years, male/female $=42 / 18$, and median (range) HCV-RNA=52 $(<5-99) \mathrm{KIU} / \mathrm{mL}$. Two of the patients treated with 48-regimen and three out of five discontinued combination therapy due to side effects had positive HCV RNA during combination therapy. Patients with negativity of serum HCV RNA during combination therapy were classified into three groups according to the difference of response: RVR $(n=18)$, EVR $(n=31)$, and LVR $(n=6)$. There were no significant differences in several factors in three groups as shown in Table 1.

\section{Safety and tolerance of IFN}

Of the 60 patients included in this study, five discontinued combination therapy because of IFN-related adverse events: one patient each with thrombocytopenia, general fa- tigue, psychiatric disorder, poor appetite, and cholecystitis. The onset of IFN-related side effects ranged from one to 11 weeks after initiation of IFN therapy. These side effects in five patients disappeared one month after cessation of IFN therapy.

Next, ten of the remaining 55 patients had dose reduction of interferon and/or ribavirin because of side effects: 5 cases of thrombocytopenia, 3 cases of general fatigue, and 2 cases of poor appetite. The onset of dose reduction due to IFNrelated side effects ranged from 1 to 26 weeks after initiation of IFN therapy.

\section{Efficacy of treatment}

Out of 60 patients enrolled in the present study, 47 patients $(78.3 \%)$ had SVR by the intention-to-treat analysis. Table 2 shows the differences in the clinical background between patients with SVR and those without SVR. The SVR was significantly associated with the attainment time of negativity of serum HCV RNA and continuance period of negative $\mathrm{HCV}$ RNA. Multivariate analysis indicated that non-relapse occurred when serum HCV RNA at week 8 was negative $(\mathrm{p}=0.004)$ and continuance of negative HCV RNA during treatment was $\geq 30$ weeks $(\mathrm{p}=0.016)$ (Table 3$)$. 
Table 2. The Difference of Clinical Backgrounds between Patients with SVR and Those without SVR

\begin{tabular}{|c|c|c|c|}
\hline & SVR（n=47） & Non-SVR (n=13) & $\mathrm{p}$ value \\
\hline Age (years old) ${ }^{\dagger}$ & $52.2 \pm 10.1$ & $53.4 \pm 8.9$ & 0.346 \\
\hline Sex $(\text { male/female })^{\dagger}$ & $35 / 12$ & $8 / 5$ & 0.488 \\
\hline BMI & $21.8 \pm 3.2$ & $22.2 \pm 3.0$ & 0.732 \\
\hline $\begin{array}{l}\text { Liver staging (non-LC } \\
\text { /LC) }\end{array}$ & $42 / 5$ & $12 / 1$ & 1.00 \\
\hline $\begin{array}{l}\text { a history of interferon } \\
(+/-)\end{array}$ & $22 / 25$ & $6 / 7$ & 1.00 \\
\hline $\begin{array}{l}\text { a history of HCV load of } \\
\geq 100 \mathrm{KIU} / \mathrm{mL}(+/-)\end{array}$ & $31 / 16$ & $7 / 6$ & 0.520 \\
\hline HCV-load $(\mathrm{KIU} / \mathrm{mL})^{*}$ & $58(<5-99)$ & $46(6-93)$ & 0.375 \\
\hline $\operatorname{AST}(\mathrm{IU} / \mathrm{L})^{*}$ & $49 \pm 34$ & $54 \pm 22$ & 0.102 \\
\hline $\operatorname{ALT}(\mathrm{IU} / \mathrm{L})^{*}$ & $70 \pm 55$ & $83 \pm 39$ & 0.082 \\
\hline Platelet $\left(10^{4} / \mathrm{mm}^{3}\right)^{*}$ & $19.0 \pm 6.5$ & $17.6 \pm 3.8$ & 0.230 \\
\hline HCV RNA (-) 4W & $17 / 46(37 \%)$ & $0 / 10(0 \%)$ & 0.023 \\
\hline HCV RNA (-) 8W & $35 / 46(76 \%)$ & $1 / 10(10 \%)$ & 0.002 \\
\hline HCV RNA (-) 12W & $44 / 46(96 \%)$ & $3 / 10(30 \%)$ & $<0.001$ \\
\hline $\begin{array}{l}\text { Continuous negative } \\
\text { period (week) }\end{array}$ & $34.9 \pm 11.6$ & $10.4 \pm 12.1$ & $<0.001$ \\
\hline $\begin{array}{l}\text { Period of IFN therapy } \\
\text { (week) }\end{array}$ & $41.6 \pm 12.6$ & $28.8 \pm 19.6$ & $<0.001$ \\
\hline
\end{tabular}

Data are number of patients, median (range) or mean \pm standard deviation. $\mathrm{p}$ value calculated by the Mann-Whitney U test

${ }^{*}$ ALT, alanine aminotransferase; AST, aspartate aminotransferase; HCV, hepatitis C virus; IFN, interferon; SVR, sustained virologic response

Table 3. Multivariate Analyses Identifying Predictors of SVR

\begin{tabular}{llccc}
\hline Factor & Category & $\begin{array}{c}\text { Odds } \\
\text { ratio }\end{array}$ & $\begin{array}{c}95 \% \text { Confidence } \\
\text { interval }\end{array}$ & p value \\
\hline HCV RNA week $8 *$ & $+/-$ & $1 / 69.1$ & $4.0-1201.4$ & 0.004 \\
\hline $\begin{array}{l}\text { Continuance period of } \\
\text { negative HCV RNA } \\
\text { during treatment (week) }\end{array}$ & $<30 / \geq 30$ & $1 / 34.5$ & $1.9-500.0$ & 0.016 \\
\hline $\begin{array}{l}\text { HCV, hepatitis C virus } \\
* \text { HCV RNA at week } 8 \text { after the initiation of treatment }\end{array}$ & & & \\
\end{tabular}

\section{SVR based on the attainment time of negativity of serum HCV RNA and continuance of negative HCV RNA}

All fifty-five patients with negativity of HCV RNA after the initiation of combination therapy had continuance of negative HCV RNA during combination therapy. SVR rate based on the attainment time of negativity of serum HCV RNA and continuance of negative HCV RNA during combination therapy are shown in Table 4 . In the RVR group, all of seven patients with continuance of negative HCV RNA of 20 to 29 week during treatment had SVR. In the EVR group, patients with continuance of 30 to 39 week during treatment had SVR of $\geq 90 \%$. In the LVR group, patients with continuance of 30 to 39 week during treatment had SVR of $50 \%$.

\section{Discussion}

We have described the efficacy of combination therapy of peginterferon and ribavirin in patients infected with $\mathrm{HCV}$ genotype $1 \mathrm{~b}$ and low virus load. The present study was limited to patients with genotype 1 and HCV-load of $<100$ $\mathrm{KIU} / \mathrm{mL}$. Another limitation is that the present study was not a randomized controlled study; thus, the treatment period was varied. Moreover, half of the patients had a history of IFN monotherapy and two-thirds of the patients had a history of maximum HCV RNA level of $>100 \mathrm{KIU} / \mathrm{mL}$. Clinical backgrounds of the enrolled patients were varied.

However, several findings from the present study have direct implications for combination therapy for chronic hepatitis $\mathrm{C}$ in the future. First, SVR was primarily associated with attainment time of negativity of serum HCV RNA and continuance of negative HCV RNA. The period of combination 
Table 4. SVR Based on the Attainment Time of Negative HCV RNA and Continuance Period of Negative HCV RNA during Combination Therapy

\begin{tabular}{lllllll}
\hline Response* & \multicolumn{2}{l}{ Continuance } & period of negative HCV RNA & (week) & \multirow{2}{*}{ Total } \\
\cline { 2 - 6 } & $<10$ & $10-19$ & $20-29$ & $30-39$ & $40-49$ & \\
\hline RVR & $100 \%$ & ND & $100 \%$ & ND & $100 \%$ & $100 \%$ \\
& $(1 / 1)$ & & $(7 / 7)$ & & $(10 / 10)$ & $(18 / 18)$ \\
EVR & ND & $63 \%$ & ND & $90 \%$ & $100 \%$ & $87 \%$ \\
& & $(5 / 8)$ & & $(9 / 10)$ & $(13 / 13)$ & $(27 / 31)$ \\
LVR & $0 \%$ & ND & ND & $50 \%$ & ND & $33 \%$ \\
& $(0 / 2)$ & & & $(2 / 4)$ & & $(2 / 6)$ \\
Total & $33 \%$ & $63 \%$ & $100 \%$ & $79 \%$ & $100 \%$ & $85 \%$ \\
& $(1 / 3)$ & $(5 / 8)$ & $(7 / 7)$ & $(11 / 14)$ & $(23 / 23)$ & $(47 / 55)$ \\
\hline
\end{tabular}

EVR, early virological response; $\mathrm{HCV}$, hepatitis C virus; LVR, late virological response; ND, not done; RVR, rapid virological response

*Response of HCV RNA means attainment time of negativity of serum HCV RNA after the initiation of combination therapy

therapy is statistically significant by univariate analysis. However, multivariate analysis showed that early undetectable HCV RNA and prolonged negativity of serum HCV RNA during treatment were associated with the SVR. In the RVR group, all seven patients with continuance of negative HCV RNA for 20 to 29 week during treatment had SVR. This result suggests that a short course regimen of 24 or < 24 week in combination therapy may be suitable for patients who have genotype 1, low virus load, and RVR. Earlier studies have reported higher SVR rates in patients with undetectable HCV RNA at week 4 compared to those with detectable HCV RNA (7-9, 23). Jensen et al (8) has reported that patients with RVR should be treated for a short course regimen. On the contrary, it may be necessary to treat patients without RVR with a long course regimen. The present results coincided closely with these earlier results.

Secondly, in the EVR group, patients with continuance of negative HCV RNA of $\geq 30$ weeks during treatment had SVR of $\geq 90 \%$. However, one-third of the patients with continuance of negative HCV RNA of 10 to19 weeks relapsed after the termination of therapy. This result suggests that patient with EVR should be given combination therapy for a year. Third, in LVR group, half of the patients with continuance of negative HCV RNA of 30 to 39 weeks during treatment had SVR. This indicates that patients with delayed undetectable HCV RNA should be treated to continue the negativity of serum HCV RNA for a prolonged period of $\geq$ one year to obtain a high rate of SVR.

A previous study (24) indicates that the suitable treatment period of combination therapy for chronic hepatitis $\mathrm{C}$ should be determined based on the time of attainment of negative
HCV RNA in patients with genotype $1 \mathrm{~b}$ and a high virus load of $\geq 100 \mathrm{KIU} / \mathrm{mL}$. Similarly, the present study suggests that in patients with genotype $1 \mathrm{~b}$ and low-virus load, the period of combination therapy should be determined based on the attainment time of negativity of serum HCV RNA.

It is desirable to expose patients with chronic hepatitis $\mathrm{C}$ to the shortest duration of treatment possible to reduce the likelihood of adverse events and minimize costs. Long-term treatment can be associated with serious side effects and is costly. HCV treatment of combination therapy is expensive; a 24-week treatment course costs approximately 20,000 dollars. Thus, the results of this study underscore the importance of changing the duration of treatment based on the difference of attainment time of negative HCV RNA. To attain SVR rate of $\geq 90 \%$ in patients with undetectable $\mathrm{HCV}$ RNA and continuance of negative HCV RNA during treatment, it is desirable to give a short course regimen of $\leq 20$ 29 weeks in the RVR group, 30-39 week in the EVR group. Moreover, in LVR, prolonged combination therapy regimen of $>48$ weeks may be recommended.

In conclusion, the period of combination therapy for chronic hepatitis $\mathrm{C}$ should be determined based on attainment time of negativity of serum HCV RNA and continuance of negative HCV RNA in patients with genotype $1 \mathrm{~b}$ and low-virus load.

\section{Acknowledgement}

The present work was supported in part by grants-in-aid from Okinaka Memorial Institute for Medical Research and the Japanese Ministry of Health, Labour and Welfare. The authors acknowledge the editorial assistance of Thomas Hughes.

\section{References}

1. Manns MP, McHutchison JG, Gordon SC, et al. Peginterferon alfa- $2 b$ plus ribavirin compared with interferon alfa- $2 b$ plus ribavirin for initial treatment of chronic hepatitis $\mathrm{C}$ : a randomised trial. Lancet 358: 958-965, 2001.
2. Fried MW, Shiffman ML, Reddy KR, et al. Peginterferon alfa-2a plus ribavirin for chronic hepatitis $\mathrm{C}$ virus infection. $\mathrm{N}$ Engl $\mathrm{J}$ Med 347: 975-982, 2002.

3. Hadziyannis SJ, Sette H, Morgan TR, et al; PEGASYS Interna- 
tional Study Group. Peginterferon-alpha2a and ribavirin combination therapy in chronic hepatitis C: a randomized study of treatment duration and ribavirin dose. Ann Intern Med 140: 346-355, 2004.

4. McHutchison JG, Manns M, Patel K, et al. Adherence to combination therapy enhances sustained response in genotype-1-infected patients with chronic hepatitis C. Gastroenterology 123: 10611069, 2002.

5. Shiffman ML, Di Bisceglie AM, Lindsay KL, et al; Hepatitis C Antiviral Long-Term Treatment Against Cirrhosis Trial Group. Peginterferon alfa- $2 \mathrm{a}$ and ribavirin in patients with chronic hepatitis $\mathrm{C}$ who have failed prior treatment. Gastroenterology 126: 1015-1023, 2004.

6. Shiffman ML, Ghany MG, Morgan TR, et al. Impact of reducing peginterferon alfa-2a and ribavirin dose during retreatment in patients with chronic hepatitis C. Gastroenterology 132: 103-112, 2007.

7. Schalm SW, Weiland $\mathrm{O}$, Hansen BE, et al. Interferon-ribavirin for chronic hepatitis $\mathrm{C}$ with and without cirrhosis: analysis of individual patient data of six controlled trials. Eurohep Study Group for Viral Hepatitis. Gastroenterology 117: 408-413, 1999.

8. Jensen DM, Morgan TR, Marcellin P, et al. Early identification of $\mathrm{HCV}$ genotype 1 patients responding to 24 weeks peginterferon alpha-2a (40 kd)/ribavirin therapy. Hepatology 43: 954-960, 2006 (Erratum in Hepatology 43: 1410, 2006).

9. Bronowicki JP, Ouzan D, Asselah T, et al. Effect of ribavirin in genotype 1 patients with hepatitis $\mathrm{C}$ responding to pegylated interferon alfa-2a plus ribavirin. Gastroenterology 131: 1040-1048, 2006.

10. Dalgard O, Bjøro K, Hellum KB, et al. Treatment with pegylated interferon and ribavarin in $\mathrm{HCV}$ infection with genotype 2 or 3 for 14 weeks: a pilot study. Hepatology 40: 1260-1265, 2004.

11. Mangia A, Santoro R, Minerva N, et al. Peginterferon alfa-2b and ribavirin for 12 vs. 24 weeks in HCV genotype 2 or 3. N Engl J Med 352: 2609-2617, 2005.

12. Bruno $S$, Cammà $C$, Di Marco $V$, et al. Peginterferon alfa-2b plus ribavirin for naïve patients with genotype 1 chronic hepatitis $\mathrm{C}$ : a randomized controlled trial. J Hepatol 41: 474-481, 2004.

13. Lindahl K, Stahle L, Bruchfeld A, et al. High-dose ribavirin in combination with standard dose peginterferon for treatment of pa- tients with chronic hepatitis C. Hepatology 41: 275-279, 2005.

14. von Wagner M, Huber M, Berg $T$, et al. Peginterferon-alpha-2a (40 KD) and ribavirin for 16 or 24 weeks in patients with genotype 2 or 3 chronic hepatitis C. Gastroenterology 129: 522-527, 2005.

15. Krawitt EL, Gordon SR, Grace ND, et al; for the New York New England Study Team. A study of low dose peginterferon alpha-2b with ribavirin for the initial treatment of chronic hepatitis C. Am J Gastroenterol 101: 1268-1273, 2006.

16. Ferenci P, Fried MW, Shiffman ML, et al. Predicting sustained virological responses in chronic hepatitis $\mathrm{C}$ patients treated with peginterferon alfa-2a (40 KD)/ribavirin. J Hepatol 43: 425-433, 2005.

17. Iwasaki $\mathrm{Y}$, Ikeda $\mathrm{H}$, Araki $\mathrm{Y}$, et al. Limitation of combination therapy of interferon and ribavirin for older patients with chronic hepatitis C. Hepatology 43: 54-63, 2006.

18. Arase Y, Suzuki F, Suzuki Y, et al. Side effects of combination therapy of peginterferon and ribavirin for chronic hepatitis-C. Intern Med 46: 1827-1832, 2007.

19. Doglio A, Laffont C, Caroli-Bosc FX, et al. Second generation of the automated Cobas Amplicor HCV assay improves sensitivity of hepatitis $\mathrm{C}$ virus RNA detection and yields results that are more clinically relevant. J Clin Microbiol 37: 1567-1569, 1999.

20. Albadalejo J, Alonso R, Antinozzi R, et al. Multicenter evaluation of the COBAS AMPLICOR HCV assay, an integrated PCR system for rapid detection of hepatitis $\mathrm{C}$ virus RNA in the diagnostic laboratory. J Clin Microbiol 36: 862-865, 1998.

21. Dusheiko G, Schmilovitz-Weiss H, Brown D, et al. Hepatitis C virus genotypes: an investigation of type-specific differences in geographic origin and disease. Hepatology 19: 13-18, 1994.

22. Desmet VJ, Gerber M, Hoofnagle JH, et al. Classification of chronic hepatitis: diagnosis, grading and staging. Hepatology 19: 1513-1520, 1994.

23. Davis GL, Wong JB, McHutchison JG, et al. Early virologic response to treatment with peginterferon alfa- $2 \mathrm{~b}$ plus ribavirin in patients with chronic hepatitis C. Hepatology 38: 645-652, 2003.

24. Arase Y, Suzuki F, Sezaki H, et al. Suitable treatment period in patients with virological response during combination therapy of peginterferon and ribavirin for chronic hepatitis C. Intern Med 47: 1301-1307, 2008.

(C) 2009 The Japanese Society of Internal Medicine http://www.naika.or.jp/imindex.html 